\title{
Penerapan Model Pembelajaran Inkuiri Terbimbing untuk Meningkatkan Pemahaman Konsep Siswa Kelas VIII pada Materi Pesawat Sederhana
}

\author{
Deski Candra $^{1}$, Haris Rosdianto ${ }^{2}$, Eka Murdani $^{3}$ \\ STKIP Singkawang, Singkawang, Indonesia \\ deskicandra@yahoo.com ${ }^{1}$, harisrosdianto@yahoo.com², ekamurdani@gmail.com³
}

\section{Kata Kunci:}

Inkuiri Terbimbing, Pemahaman

Konsep, Pesawat Sederhana

\begin{abstract}
ABSTRAK
Penelitian ini bertujuan untuk mendapatkan gambaran mengenai peningkatan pemahaman konsep siswa setelah menerapkan model pembelajaran inkuiri terbimbing pada materi pesawat sederhana. Jenis penelitian ini adalah kuantitatif dengan bentuk penelitian pre-experiment dan rancangan one group pre-test post-test design. Populasi dalam penelitian ini adalah seluruh siswa kelas VIII di salah satu SMP kota Singkawang, sampel penelitian siswa kelas VIII A yang berjumlah 25 orang, dengan teknik pengambilan sampel menggunakan purposive sampling. Alat ukur tes berupa 15 soal pilihan ganda tentang pemahaman konsep yang sebelumnya diujicobakan terlebih dahulu. Hasil analisis data test pemahaman konsep menggunakan persamaan $\mathrm{N}$-gain, peningkatan pemahaman konsep siswa sebesar 0,65 dengan kategori sedang.
\end{abstract}

\section{PENDAHULUAN}

Ilmu Pengetahuan Alam (IPA) merupakan cara mencari tahu tentang alam secara sistematis, yang berupafakta-fakta, konsep-konsep, prinsip-prinsip serta merupakan suatu proses penemuan. Pendidikan IPA diharapkan dapat menjadi wahana bagi peserta didik untuk mempelajari diri sendiri dan alam sekitar, serta prospek pengembangan lebih lanjut dalam menerapkannya di dalam kehidupan sehari-hari. Penerapan pembelajaran IPA di SMP/MTs lebih ditekankan pada pemberian pengalaman belajar secara langsung untuk mengembangkan kompetensi agar menjelajahi dan memahami alam sekitar secara ilmiah (Permendiknas, 2006: 377).

Pembelajaran IPA idealnya harus dapat menumbuhkan minat siswa pada awal kegiatan maupun akhir kegiatan pembelajaran, dan kegiatan pembelajaran dilakukan secara interaktif, inspiratif, menyenangkan, menantang, memotivasi peserta didik untuk berpartisipasi aktif, serta memberikan ruang yang cukup bagi prakarsa, kreativitas, dan kemandirian sesuai dengan bakat, minat, perkembangan fisik serta psikologis peserta didik (Sudrajat, 2009: 22). Dengan pembelajaran tersebut siswa akan lebih mudah untuk memahami konsep-konsep pada pelajaran IPA (Rosdianto dkk., 2017; Murdani \& Sumarli, 2019).

Pemahaman konsep adalah kemampuan siswa yang berupa penguasaan sejumlah materi pelajaran, dimana siswa tidak sekedar mengetahui atau mengingat sejumlah konsep yang dipelajari, tetapi mampu mengungkapan kembali dalam bentuk lain yang mudah dimengerti, memberikan interprestasi 
data dan mampu mengaplikasikan konsep yang sesuai dengan struktur kognitif yang dimilikinya (Patria, 2007:21; Rosdianto, 2017; Murdani, Sumarli, \& Buyung, 2018).

Rendahnya rata-rata perolehan nilai pada pelajaran Fisika disebabkan konsep Fisika yang selama ini disampaikan guru kepada siswa sebagai fakta bukan sebagai peristiwa atau gejala alam yang harus diamati, diukur, maupun didiskusikan (Affandi, 2010: 2). Rendahnya pemahaman konsep Fisika Siswa dipengaruhi oleh salah satu faktor yaitu proses pembelajaran (Sardiman, 2003: 97). Pembelajaran Fisika yang selama ini dilaksanakan oleh guru masih menganut pada teori tabula, otak seorang anak adalah ibarat botol kosong yang siap diisi dengan segala ilmu pengetahuan dan kebijaksanaan guru.

Berdasarkan pengamatan yang telah dilakukan di salah satu SMP Singkawang Timur, dilihat dari hasil ulangan harian siswa pada materi Pesawat Sederhana diperoleh bahwa banyak siswa yang memperoleh nilai di bawah KKM (Kriteria Ketuntasan Minimal). KKM yang ditentukan oleh sekolah adalah 75 . Berdasarkan KKM maka persentase yang diperoleh dari rekap nilai guru adalah 40\% siswa tuntas dan 60\% siswa tidak tuntas. Dari hasil tersebut dapat disimpulkan bahwa rata-rata pemahaman konsep siswa hasilnya tidak memuaskan. Hal ini dikarenakan pembelajaran yang sering diterapkan guru bersifat monoton yaitu siswa hanya duduk diam, melihat dan mendengarkan guru berbicara di depan kelas, juga kurangnya kesempatan siswa untuk berfikir mandiri mengembangkan konsep-konsep materi Fisika, terutama materi Pesawat Sederhana.

Metode pembelajaran yang sesuai untuk hal tersebut adalah inkuiri terbimbing karena berdasarkan penelitian Ambarsari dkk. (2013), inkuiri terbimbing merupakan suatu cara yang efektif untuk membuat variasi suasana pola pembelajaran kelas. Pembelajaran inkuiri terbimbing merupakan pembelajaran kelompok dimana siswa diberi kesempatan untuk berfikir mandiri dan saling membantu dengan teman yang lain. Pembelajaran inkuiri terbimbing membimbing siswa untuk memiliki tanggung jawab individu dan tanggung jawab dalam kelompok atau pasangannya. Terbukti bahwa dengan menerapkan Inkuiri Terbimbing menunjukkan peningkatan keaktifan siswa dan pemahaman konsep siswa sangat baik (Sulistyo, 2006).

\section{METODE PENELITIAN}

Jenis penelitian yang digunakan adalah penelitian kuantitatif, dengan metode pre-experiment. Desain penelitian yang digunakan adalah One Group Pretest-Posttest Design (Sugiyono, 2008). Populasi dalam penelitian ini adalah seluruh siswa kelas VIII di salah satu SMPN di kota Singkawang Timur dengan teknik purposive sampling. Teknik pengumpulan data dalam penelitian ini berupa test, adapun test yang digunakan adalah berupa pre-test dan post-test. Sebelum test digunakan dalam penelitian, terlebih dahulu test diuji cobakan.

\section{HASIL DAN PEMBAHASAN}

Hasil belajar siswa diukur dengan menggunakan soal pretest dan posttest. Adapun aspek pemahaman konsep yang digunakan terdiri dari aspek Menjelaskan, mengklasifikasikan, membandingkan, mencontohkan, dan menafsirkan. Setelah mendapat data hasil pretest dan posttest, kemudian data dianalisis menggunakan uji gain yang ternormalisasi ( $N$-gain) (Hake, 1999). Uji $N$-gain digunakan untuk mendapat gambaran peningkatan hasil belajar siswa setelah diberikan pretest dan posttest. Untuk menentukan peningkatan hasil belajar diperoleh dari hasil analisis dengan menggunakan $\mathrm{N}$ gain. Pada aspek Menjelaskan terjadi peningkatan skor pretest ke posttest sebanyak 35 poin, yaitu dari skor yang semula 40 menjadi 75. Pada aspek mengklasifikasikan terjadi peningkatan skor pretest ke posttest sebanyak 44 poin, yaitu dari skor yang semula 36 menjadi 80 . Pada aspek Membandingkan terjadi peningkatan skor pretest ke posttest sebanyak 50 poin, yaitu dari skor yang semula 35 menjadi 85. Pada aspek Mencontohkan terjadi peningkatan skor pretest ke posttest sebanyak 45 poin, yaitu dari skor yang semula 50 menjadi 95. Pada aspek Menafsirkan terjadi peningkatan skor pretest ke posttest sebanyak 50 poin, yaitu dari skor yang semula 24 menjadi 74 . Jumlah skor maksimal untuk seluruh aspek adalah 100 Adapun peningkatan hasil belajar tiap aspek 
ditampilkan pada Tabel 1, dan Grafik yang menunjukkan rekapitulasi data peningkatan skor pretest ke posttest ditampilkan pada Gambar 1.

Tabel 1. Peningkatan Pemahaman Konsep Tiap Aspek

\begin{tabular}{|c|c|c|c|c|}
\hline \multirow{2}{*}{ Aspek Pemahaman Konsep } & \multicolumn{2}{|c|}{ Nilai } & \multirow{2}{*}{$N$-gain } & \multirow{2}{*}{ Kategori } \\
\hline & Pre-test & Post-test & & \\
\hline Menjelaskan & 40 & 75 & 0,58 & Sedang \\
\hline Mengklasifikasikan & 36 & 80 & 0,69 & Sedang \\
\hline Membandingkan & 35 & 85 & 0,77 & Tinggi \\
\hline Mencontohkan & 50 & 95 & 0,90 & Tinggi \\
\hline Menafsirkan & 24 & 74 & 0,66 & Sedang \\
\hline
\end{tabular}

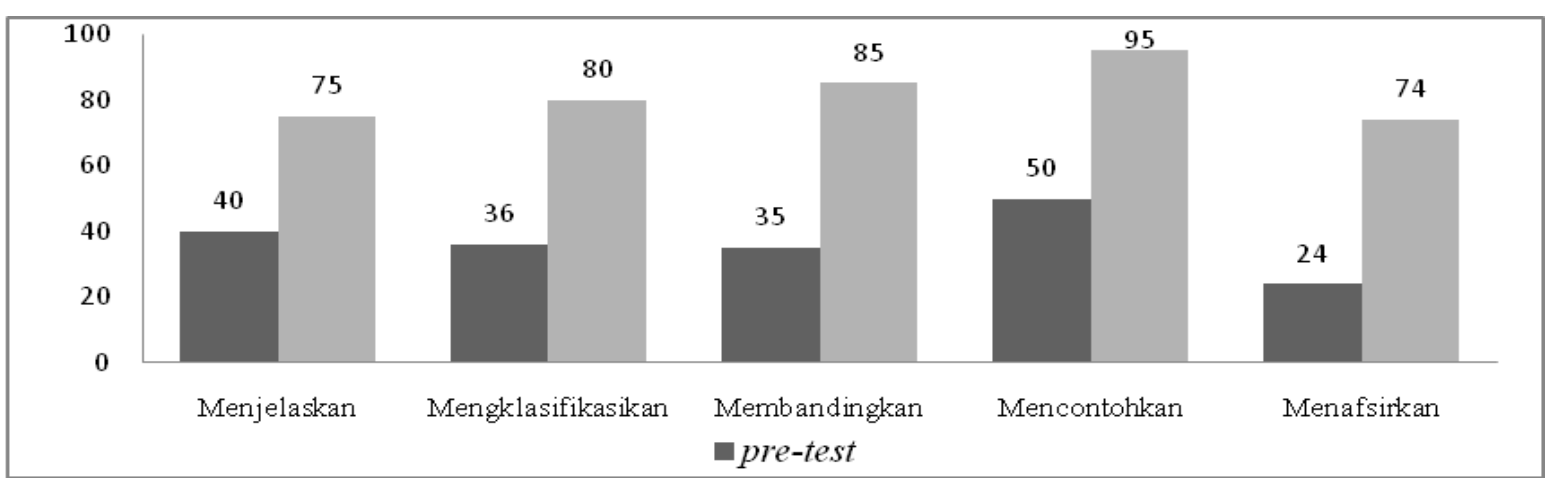

Gambar 1. Grafik peningkatan skor pretest ke posttest

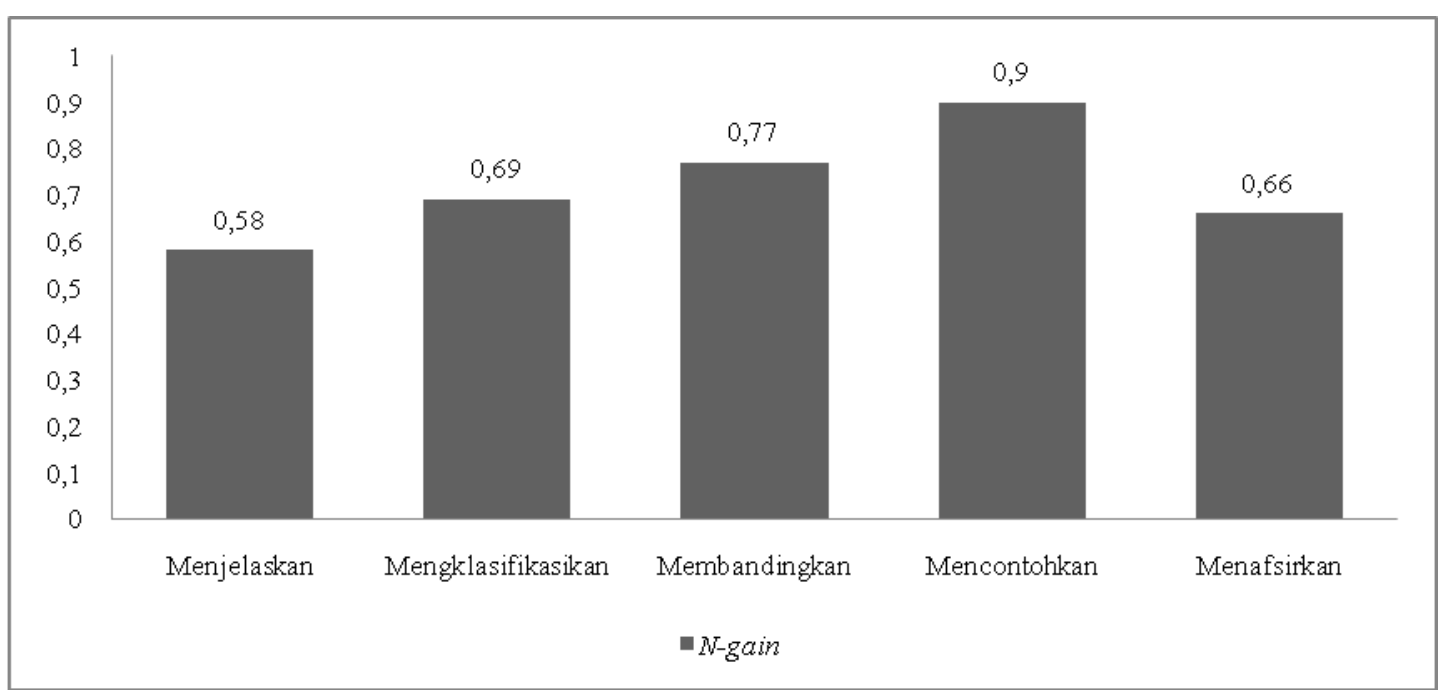

Gambar 2. Grafik hasil peningkatan pemahaman siswa dengan menggunakan N-gain

Pada penelitian yang dilaksanakan di kelas VIII salah satu SMP Kota Singkawang dengan penerapan model pembelajaran inkuiri terbimbing pada materi pesawat sederhana. Menghasilkan peningkatan pemahaman konsep siswa yang diketahui dari hasil analisis pada setiap aspek dengan menggunakan $\mathrm{N}$-gain. Adapun peningkatan yang dihasilkan pada aspek menjelaskan yaitu sebesar 0,58 dengan kategorisedang dan aspek mengklasifikasikan yaitu sebesar0,69 dengan kategori sedang. Pada aspek menbandingkan yaitu sebesar 0,77 dengan kategori tinggi.pada aspek mencontohkan mencapai 0,90 dengan kategori tinggi, dan aspek menafsirkan yaitu sebesar 0,66. Dapat disimpulkan bahwa pada 
setiap aspek mengalami peningkatan pemahaman konsep dengan diperoleh peningkatan pemahaman kosep menggunakan persamaan $\mathrm{N}$-gain yaitu sebesar 0,65 dengan kategori sedang. Hal ini membuktikan bahwa model pembelajaran inkuiri terbimbing dapat meningkatkan pemahaman konsep siswa kelas VIII pada materi Peswat Sederhana, ini juga terbukti bahwa dengan menerapkan Inkuiri Terbimbing menunjukkan peningkatan keaktifan siswa dan pemahaman konsep siswa sangat baik (Sulistyo 2006).

\section{KESIMPULAN}

Berdasarkan analisis yang dilakukan, secara umum dapat disimpulkan bahwa model inkuiri terbimbing dapat meningkatkan pemahaman konsep siswa pada materi pesawat sederhana di kelas VIII, peningkatan pemahaman konsep siswa sebesar 0,65 dengan kategori sedang.

\section{DAFTAR PUSTAKA}

Affandi, Irfan. (2010). Persepsi Terhadap Pendidikan Inklusi. Skripsi. Universitas Sumatra Utara.

Ambarsari, Wiwin. (2013). Penerapan Pembelajaran Inkuiri Terbimbing Terhadap Keterampilan Proses Sains Dasar Pada Pembelajaran Biologi Siswa Kelas VIII SMP Negeri 7 Surakarta. Surakarta: FKIP-UNS.

Hake, Richard R. (1999). Analyzing Change/Gain Scores. Tersedia: www.physics.indiana.edu/ sdi/AnalyzingChange-Gain.pdf. pp. 81-95.

Murdani, E., \& Sumarli, S. (2019). Student Learning by Experiment Method for Analyzing the Dynamic Electrical Circuit and Its Application in Daily Life. In Journal of Physics: Conference Series, 1153(1), 012119. IOP Publishing.

Murdani, E., Sumarli \& Buyung. (2018). Improving the Student Conceptual Understanding of the Static Fluid Material by Using the Model of Children Learning in Science. In 3rd Annual International Seminar on Transformative Education and Educational Leadership (AISTEEL 2018). Atlantis Press.

Patria. (2007). Pemahaman konsep. (online). Tersedia di http://media harja.blogspot.com/2011/pemahaman-konsep.html?m=1 (Diakses pada tanggal 16-05-2016 pada pukul 21:20).

Permendiknas. (2006). Peraturan Menteri Pendidikan Nasional No 22 tahun 2006 tentang Standar Isi Pendidikan Dasar dan Menengah. Jakarta: CV Eko jaya.

Rosdianto, H. (2017). Students' Conceptual Understandy through Generative Learning Model in Top "Light". JPI (Jurnal Pendidikan Indonesia), 6(2), 259-262.

Rosdianto, H., Murdani, E., \& Hendra. (2017). Implementasi Model Pembelajaran POE (Predict Observe Explain) Untuk Meningkatkan Pemahaman Konsep Siswa Pada Materi Hukum Newton. Jurnal Pendidikan Fisika, 6(1), 55-57.

Sardiman. (2003). Interaksi dan Motivasi Belajar Mengajar.Jakarta: PT raja Grafindo Persada.

Sudrajat. (2009). Pengertian Pendekatan, Strategi, Metode, Tehnik Dan Model Pembelajaran. Bandung: Sinar Baru Algensindo.

Sugiyono. (2008). Metode Penelitian Pendidikan. Bandung: Alfabeta.

Sulistyo, Basuki. (2006). metode penelitian. Jakarta: Wedatama Widya Sastra. 